\title{
MANAJEMEN KONFLIK PENYELESAIAN KASUS REKLAMASI PULAU G PANTAI UTARA JAKARTA
}

\author{
Antik Bintari, S.IP., MT \\ Talolo Muara, S.IP ${ }^{2}$ \\ ${ }^{1}$ Program Studi Ilmu Pemerintahan FISIP Universitas Padjadjaran \\ ${ }^{2}$ Program Studi Ilmu Pemerintahan FISIP Universitas Padjadjaran \\ Email: antikisw@gmail.com
}

\begin{abstract}
ABSTRAK
Kebijakan merupakan suatu keputusan yang diambil oleh pemerintah dari berbagai alternatif yang ada. Salah satu kebijakan pemerintah Provinsi Daerah Khusus Ibukota Jakarta adalah pengembangan ke arah utara dengan melakukan reklamasi Pantai Utara Jakarta. Namun dalam pelaksanaannya, kebijakan tersebut ditentang oleh masyarakat Muara Angke dan Lembaga Swadaya Masyarakat. Dengan adanya pertentangan tersebut diperlukan pengelolaan konflik. Makalah ini bertujuan untuk menganalisis konflik melalui apa yang dikenal dengan manajemen konflik beserta fase-fase konflik reklamasi Pulau G Pantai Utara Jakarta. Fase-fase konflik meliputi fase potensi konflik, fase pertumbuhan konflik, fase pemicu dan ekskalasi, dan fase pasca konflik. Temuan-temuan empiris memperlihatkan bahwa, fase potensi konflik reklamasi Pulau $G$ ini dimulai oleh dampak yang dirasakan masyarakat terutama nelayan tradisional dan tidak adanya sosialisasi dari Pemerintah Provinsi DKI Jakarta. Kemudian, pada fase pertumbuhan konflik, masyarakat mengetahui apa itu reklamasi dan dampak reklamasi melalui sosialisasi yang dilakukan oleh lembaga swadaya masyarakat. Pada fase pemicu dan ekskalasi, masalah tersebut disuarakan oleh masyarakat kepada Pemerintah Provinsi DKI Jakarta dengan bantuan lembaga swadaya masyarakat. Kemudian, fase pasca konflik diawali dengan dikeluarkannya sanksi administrasi penghentian sementara reklamasi Pulau G oleh Kementerian Lingkungan Hidup dan Kehutanan.
\end{abstract}

Kata Kunci: Konflik, Manajemen Konflik, Reklamasi

\begin{abstract}
Policy is about decision taken by government of various the alternatives. One of policy of Provincian Government Special Capital Region of Jakarta (Provincial Government DKI Jakarta) is development toward the north by doing reclamation North Shore Jakarta. However in implementation, the policy are opposite by Muara Angke society and Civil Society. With the opposition, conflict management are necesarry. This paper aims to analyze the conflict through what is known as conflict management and the phases of the conflict of reclamation of Pulau $G$ Pantai Utara Jakarta. Conflict phase includes potential potential conflict phase, gestation phase, trigger and escalation phase, and post-conflict phase. The empirical findings show that, potential conflict phase reclamation of Island $G$ was started by perceived impact of society especially traditional fisherman and absence of socialization and transparency from Provincial Government of DKI Jakarta. Next, in gestation phase, society know what it is reclamation and impact of reclamation through socialization by civil society. Then, in trigger and escalation phase, the problem is submitted by society to Provincial Govenment of DKI Jakarta with aid
\end{abstract}


Vol.4, No.1, April 2018

from civil society. Finnaly, in post-conflict phase, initiated with released of administrative sanction temporary cessation reclamation of Island $G$ by Ministry of Environment and Forestry.

Keywords: Conflict, Conflict management, Reclamation

\section{PENDAHULUAN}

Desakan akan besarnya kebutuhan lahan untuk kegiatan pembangunan terutama di kawasankawasan yang akan berubah menuju kawasan perkotaan pada saat sekarang ini mengalami peningkatan sangat pesat. Salah satunya dilakukan melalui kebijakan yang dikenal dengan istilah reklamasi. Reklamasi adalah suatu pekerjaan/usaha memanfaatkan kawasan atau lahan yang relatif tidak berguna atau masih kosong dan berair menjadi lahan berguna dengan cara dikeringkan. Pada dasaranya reklamasi merupakan kegiatan merubah wilayah perairan pantai menjadidaratan.Di Indonesia, reklamasi akan dilaksanakan diberbagai lokasi salah satunya di Provinsi Daerah Khusus Ibukota Jakarta (Provinsi DKI Jakarta) tepatnya di Pantai Utara Jakarta. Provinsi DKI Jakarta merupakan ibukota negara Indonesia dan sekaligus merupakan pusat pemerintahan, bisnis, dan keuangan dan jasa di Indonesia.

Rencana dilakukannya reklamasi sudah ada sejak Provinsi DKI Jakarta dipimpin oleh Gubernur Wiyogo Atmodarminto. Rencana Pemerintah Provinsi DKI Jakarta tersebut direspon oleh Presiden
Soeharto dengan menerbitkan Surat Keputusan Nomor 52 Tahun 1995 Tentang Reklamasi Pantai Utara Jakarta. Berdasarkan Keputusan Presiden tersebut, reklamasi Pantai Utara Jakarta merupakan wewenang Gubernur Provinsi DKI Jakarta. Kebijakan reklamasi diikuti dengan pembentukan Komisi Penilai Analisis Mengenai Dampak Lingkungan (Komisi Penilai AMDAL) yang dibentuk oleh Kementerian Lingkungan Hidup pada tahun 1996. Pada tahun 1999, ketika AMDAL dikeluarkan oleh Presiden, Kementerian Lingkungan Hidup mengatakan bahwa reklamasi Pantai Utara Jakarta berbahaya bagi kelangsungan ekosistem sekitar dan berdampak bagi masyarakat terutama nelayan. Oleh karena itu, pada tahun 2003, Menteri Lingkungan Hidup mengeluarkan Surat Keputusan Menteri Lingkungan Hidup Nomor 14 Tahun 2003 Tentang Ketidaklayakan Rencana Kegiatan dan Revitalisasi Pantai Utara.

Surat Keputusan Menteri Lingkungan Hidup tersebut kemudian digugat oleh enam pengembang ke Pengadilan Tata Usaha Negara (PTUN) dan dimenangkan oleh pengembang. Kemudian, Kementerian Lingkungan Hidup mengajukan banding atas 
Vol.4, No.1, April 2018

keputusan PTUN tetapi masih dimenangkan oleh pengembang. Tidak berhenti disitu, pada tahun 2009, Kementerian Lingkungan Hidup mengajukan kasasi ke Mahkamah Agung berkaitan dengan Reklamasi menyalahi AMDAL dan diterima oleh Mahkamah Agung. Kemudian, pada tahun 2011, pengembang pulau reklamasi Pantai Utara Jakarta mengajukan penijauan kembali terhadap kasasi Kementerian Lingkungan Hidup. Peninjauan kasasi oleh pengembang diterima oleh Mahkamah Agung. Dalam putusannya dikatakan bahwa Kementerian Lingkungan Hidup merupakan tim pengarah Gubernur Provinsi DKI Jakarta sebagai Badan Pengendali Reklamasi Pantai Utara Jakarta. Selain itu, putusan tersebut dikatakan bahwa Presiden Republik Indonesia adalah pihak yang dapat memberhentikan reklamasi karena adanya kelemahan AMDAL.

Sampai saat ini, sudah terdapat 4 pulau hasil reklamasi dari rencana pembuatan 17 pulau yaitu Pulau C, D, G, dan N. Reklamasi Pulau C dan D dimulai tahun 2012, Pulau N pada tahun 2013, dan Pulau G pada tahun 2015. Konflik Reklamasi Pantai Utara Jakarta yang menjadi perhatian peneliti adalah Reklamasi Pulau G karena kemunculan lembaga swadaya masyarakat dan pihak yang berkepentingan pada tahun 2015 setelah izin pelaksanaan diterbitkan pada 23 Desember 2014. Munculnya lembaga swadaya masyarakat memberikan pemahaman kepada masyarakat Muara Angke terkait reklamasi. Lembaga Swadaya Masyarakat ini membentuk sebuah koalisi untuk menyatukan fokus dan gerakan yaitu Koalisi Selamatkan Teluk Jakarta. Sebelum kedatangan LSM, masyarakat Muara Angke sudah merasakan dampak reklamasi bagi mata pencahariannya. Mereka merasakan hasil tangkapan berkurang, membutuhkan biaya yang lebih besar karena rute perjalanan yang lebih jauh karena harus mengelilingi pulau reklamasi, adanya isu pemindahan nelayan ke Kepulauan Seribu, dan hilangnya lokasi budidaya ikan dan kerang hijau. Dengan kemunculan LSM memberikan kesadaran dan bantuan bagi masyarakat Muara Angke untuk bergerak mengajukan gugatan ke PTUN.

Menanggapi permasalahan tersebut, pada tahun 2016, Pemerintah Pusat memerintahkan Menteri Koordinator Kemaritiman Republik Indonesia untuk menyelesaikan konflik tersebut. Menteri Koordinator Kemaritiman kemudian membentuk Komite Bersama Pantai Utara Jakarta yang terdiri dari Kementerian Koordinator Kemaritiman, Kementerian Lingkugan Hidup dan Kehutanan, Kementerian Kelautan dan Perikanan, Kementerian Perhubungan, dan Pemerintah Provinsi DKI Jakarta. Dalam putusan Komite tersebut, berdasarkan 
berbagai pertimbangan, reklamasi Pulau G Pantai Utara Jakarta tergolong dalam pelanggaran berat sehingga diberhentikan secara permanen. Pada saat itu, Menteri Koordinator Kemaritiman adalah Rizal Ramli. Pertama, aspek hukum karena bertentangan dengan Pasal 11 Keputusan Presiden Nomor 52 Tahun 1995 yaitu membahayakan lingkungan, membahayakan lalu lintas laut, berada dekat dengan istalasi listrik Muara Karang. Selain itu, bertentangan dengan Peraturan Pemerintah Nomor 5 Tahun 2010 tentang Kenavigasian karena dalam peraturan tersebut dikatakan bahwa bila ada pipa gas di bawah laut harus bebas 500 meter di kiri dan kanan sedangkan pipa gas jaraknya 25-40 meter dari Pulau G. Keadaan ini dapat meningkatkan suhu bawah laut $2^{0}$ dan menurunkan kapasitas mesin dan berdampak pada listrik yang dihasilkan turun. Kedua, aspek ekonomi karena nelayan harus melaut lebih jauh dan berdampak pada bahan bakar yang dibutuhkan. Selain itu, kenaikan biaya bahan bakar tidak diimbangi oleh kenaikan harga ikan hasil tangkapan sehingga nelayan merugi. Ketiga, aspek sosial karena bau tidak sedap yang dihasilkan dari kontaminasi bahan kimia, air asin, dan sinar matahari sehingga masyarakat menjadi kurang nyaman. Keempat, aspek politik karena berdasarkan kajian Pembangunan Kelautan dan Peradaban Maritim, potensi kerugian ekonomi dan sosial reklamasi Pantai Utara Jakarta sebesar 661,31 Triliun diakibatkan oleh kerusakan sumber daya alam dan semakin meluasnya kemiskinan.

Akan tetapi, setelah kajian dihasilkan, Menteri Koordinator Kemaritiman Rizal Ramli diganti oleh Luhut Binsar Panjaitan. Berbeda dengan Menteri Koordinator Kemaritiman sebelumnya, Luhut ingin reklamasi Pulau $G$ tetap dilanjutkan. Alasan dilanjutkannya reklamasi menurutnya adalah mempertahankan reputasi Indonesia di mata investor karena rencana sudah ada sejak zaman Pemerintahan Soeharto, sudah menemukan solusi dalam

menanggapi dampak reklamasi Pulau $\mathrm{G}$, telah melakukan sosialisasi dengan PLN, Pertamina, Kementerian, dan Lembaga Pemerintahan dan sudah diputuskan untuk mencabut moratorium. Menanggapi kebijakan dari Menteri Koordinator Kemaritiman yang baru, Koalisi Selamatkan Teluk Jakarta membuat somasi sebagai peringatan kepada pemerintah untuk menjalankan putusan PTUN Nomor 193/G/LH/2015/PTUN-JKT yang diterbitkan $\quad 10 \quad$ mei 2016. ${ }^{1}$ Permasalahan yang

Koalisi Selamatkan Teluk Jakarta. 2016. Somasi Terbuka Menolak Dilanjutkannya Reklamasi Teluk Jakarta. Tersedia di http://www.bantuanhukum.or.id/web/so masi-terbuka-menolak-dilanjutkannya- 
Vol.4, No.1, April 2018

dikemukakan dalam makalah ini adalah bagaimana fase-fase konflik Reklamasi Pulau G Pantai Utara Jakarta pada tahun 2015-2016.

\section{KERANGKA TEORI}

\section{Manajemen Konflik}

Dalam fenomena interaksi dan interelasi sosial antar individu maupun

antar kelompok, terjadinya konflik sebenarnya merupakan hal yang wajar.

Pada awalnya konflik dianggap sebagai gejala atau fenomena yang tidak wajar dan berakibat negatif, tetapi sekarang konflik dianggap sebagai gejala alamiah yang dapat berakibat negatif maupun positif tergantung bagaimana cara mengelolanya. Joel D. DiGirolamo (Wirawan, 2013) mendefinisikan bahwa konflik adalah sebuah proses yang diawali ketika individu atau kelompok merasakan adanya perbedaan dan pertentangan antara individu sendiri dan individu yang lain atau kelompok kepentingan, sumber daya, keyakinan, nilai, atau kenyataan yang terjadi kepada mereka. Konflik dapat memberikan dampak positif dan negatif bagi pihak yang berkonflik. Dampak positifnya adalah menciptakan perubahan dan mengembangkan kehidupan manusia, mendorong kreativitas

reklamasi-teluk-jakarta/ (diakses 29 September 2016) dalam menghadapi konflik, terciptanya solusi terbaik agar tercipta interaksi sosial yang harmonis, dan menciptakan revitalisasi norma. Sedangkan dampak negatif konflik adalah memerlukan biaya dan energi berupa fisik, psikologi, uang, waktu, dan peralatan, menurunkan hubungan dan komunikasi antar pihak yang terlibat, merusak organisasi, menurunkan mutu pengambilan keputusan, menurunkan produktivitas pekerjaan, dan mengganggu kesehatan pihak yang berkonflik.

Perilaku pihak yang berkonflik adalah tindakan koersif dan tindakan nonkoersif. Tindakan koersif adalah tindakan sosial yang memaksa pihak lawan untuk melakukan sesuatu yang pihak lawan tidak ingin melakukannya. Sedangkan tindakan nonkoersif adalah mencari jalan keluar dalam hubungan konflik. Tindakan ini didasari oleh kesadaran pentingnya pemecahan masalah dan biasanya dilakukan dengan melakukan negoisasi. Tindakan nonkoersif ini dapat digunakan sebagai strategi konflik sebelum tindakan koersif. Terdapat beberapa tipe konflik. Pertama, tanpa konflik yaitu situasi yang relatif stabil dimana antar kelompok saling mememuhi dan damai. Kedua, konflik laten yaitu situasi dimana suatu konflik yang tersembunyi dan diperlukan upaya untuk mengangkat masalah tersebut agar dapat ditangani. Ketiga, konflik terbuka 
yaitu situasi dimana konflik sudah naik ke permukaan, berakar, nyata, dan memerlukan tindakan untuk mengatasi akar penyebab dan berbagai efeknya. Keempat, konflik dipermukaan adalah situasi dimana konflik terjadi karena kesalahpahaman mengenai sasaran.

Donald Rotchild dan Chandra Lekra Sriram (Wirawan, 2013) membagi konflik menjadi empat fase. Pertama, fase potensi konflik yaitu konflik terjadi dalam intensitas rendah dan belum terdapat kelompok-kelompok dalam masyarakat. Pada fase ini, tindakan preventif memiliki potensi untuk berhasil. Kedua, fase pertumbuhan konflik yaitu isu yang dipertentangkan sudah didefinisikan dan terdapat kelompok yang terorganisasi. Pada fase ini, kekerasan mungkin terjadi tetapi isu yang dipertentangkan masih dapat didiskusikan. Biaya tindakan preventif meningkat tetapi masih memiliki potensi untuk berhasil. Ketiga, fase pemicu dan ekskalasi yaitu konflik yang diakibatkan perubahan nyata dalam kelompok berupa kondisi ekonomi, sosial, atau politik. Pada fase ini, kekerasan meningkat dan kelompok yang bertikai kehilangan kepercayaan satu sama lain. Pada fase ini, tindakan untuk mecegah kekerasan agar tidak berekskalasi ke kelompok lain masih mungkin dilakukan. Keempat, fase pasca konflik adalah pihak yang berkonflik membangun kembali hubungan damai dan saluran komunikasi diantara kelompok yang terlibat konflik untuk menghindari terjadinya kekerasan. Dalam penelitian ini juga, diperlukan pemetaan konflik untuk menganalisis konflik yang terjadi. Teknik pemetaan konflik menurut Wehr dan Bartos adalah menelusuri sejarah konflik, dan bentuk asli dan tata organisasi yang berkonflik; menemukan siapakah pihak yang berkonflik; memisahkan apa yang menjadi sebab, akar, dan akibat sampingan dari konflik; sasaran selama proses konflik secara spesifik; perkembangan situasi yang dibentuk oleh berbagai model tindakan para pihak yang berkonflik; menemukan bentuk perilaku yang memungkinkan konflik mengarah pada penyelesaian; dan bagaimana aturan legal dapat campur tangan atau menggawangi proses konflik.

Menurut Wirawan manajemen konflik adalah proses pihak yang terlibat konflik atau pihak ketiga menyusun strategi konflik dan menerapkannya untuk mengendalikan konflik agar menghasilkan resolusi yang diinginkan. Dalam upaya penyelesaian konflik (Forum Akademisi Papua Damai, 6), terdapat beberapa tindakan yang dapat dilakukan oleh pihak yang berkonflik. Pertama, kemauan pemerintah untuk menyelesaikan konflik dengan melakukan dialog, negosiasi, dan hasil yang dicapai 
terhadap pihak yang berkonflik. Kedua, terpenuhinya dialog terbuka, tanpa syarat, dan tanpa pemenuhan komitmen tertentu. Ketiga, mengidentifikasi aktor kunci dan kemungkinan mitra yang berperan dalam penyelesaian konflik berupa pembuatan keputusan di dalam organisasi masing-masing. Keempat, terbuka terhadap pihak ketiga di dalam memfasilitasi kelancaran dialog dalam penyelesaian konflik. Kelima, komitmen bersama untuk fokus dan disiplin terhadap keseluruhan dialog dan negosiasi penyelesaian konflik. Bentuk dan proses penyelesaian konflik dapat dilakukan dengan membiarkan dengan mengharapkan konflik selesai dengan sendirinya, setuju menyelesaikan masalah secara informal dan formal, munculnya pihak ketiga, dan lembaga peradilan yang netral untuk menyelesaikan konflik.

\section{Reklamasi}

Indonesia sebagai negara kepulauan dan negara maritim yang mempunyai garis pantai terpanjang kedua di dunia setelah Canada dan keanekaragaman hayati pesisir dan laut terbesar di dunia. Indonesia memiliki 13.466 pulau dan luas daratan 5,8 juta $\mathrm{km}^{2}$ termasuk Zona Ekonomi Eksklusif $^{2}$ dan dikelilingi

2 Zona ekonomi eksklusif adalah zona 200 mil laut dari garis pantai. Pada zona ini, pemerintah Indonesia memiliki hak mengatur segala kegiatan eksplorasi dan eksploitasi sumberdaya alam di
95.181 garis pantai. Keadaan geografis tersebut memberikan keuntungan bagi Indonesia yaitu kekayaan laut yang besar meliputi sumber daya terbarukan dan sumber daya tidak terbarukan. ${ }^{3}$ Dalam satu dekade terakhir, Pemerintah Daerah cenderung memperluas wilayahnya ke arah laut pesisir dengan cara menimbun, mereklamasi, dan menebang habis hutan mangrove. Dampak negatifnya adalah menghilangkan habitat organisme laut di padang lamun, burung-burung yang mencari makan di laut, abrasi, serangan nyamuk di pemukiman masyarakat, dan hilangnya fungsi alamiah mangrove. Paradigma pembangunan wilayah pesisir yang bersifat sektoral menimbulkan berbagai permasalahan dan konflik sosial. Permasalahan muncul karena sumberdaya yang menopang kehidupan sosial ekonomi banyak orang dan jangka panjang bisa dikendalikan oleh kegiatan pembangunan yang dinikmati secara ekonomi oleh sedikit orang dalam

permukaan dan dalam, dan dasar laut, serta mengadakan penelitan sumber daya hayati dan sumber daya laut lainya. (Ilmu Geografi[dot]com. Zona Ekonomi Eksklusif : Pengertian, Sejarah, Batas, Fungsi dan Kegiatan. Tersedia di https://ilmugeografi.com/ilmubumi/laut/zona-ekonomi-eksklusif (diakses 30 Oktober 2017))

3 Sumber daya terbarukan meliputi mangrove, terumbu karang, rumput laut, dan padang lamun. Sumber daya tidak terbarukan meliputi minyak dan gas bumi, timah, biji besi, bauksit, dan mineral lainnya. 
jangka waktu yang pendek. Keadaan ini terjadi ketika pemerintah menyadari pentingnya sumber daya wilayah pesisir dengan memanfaatkan ketidakberdayaan masyarakat pesisir tanpa upaya menghindari persoalan ekonomi sosial masyarakat.

Reklamasi merupakan kegiatan yang dilakuksn oleh orang dalam rangka meningkatkan manfaat sumber daya lahan ditinjau dari sudut lingkungan dan sosial ekonomi dengan cara pengurugan, pengeringan lahan, atau drainase. Sebelum pelaksanaan reklamasi, diperlukan AMDAL sebagai alat merencanakan tindakan preventif terhadap kerusakan lingkungan yang mungkin akan ditimbulkan oleh aktivitas pembangunan yang sedang direncanakan. Tujuan dasar kajian AMDAL adalah pertimbangan lingkungan dalam proses perencanaan pembuatan program dan pengambilan keputusan. Selain itu, melindungi lingkungan dari pembangunan yang tidak bijaksana dan dampak aktivitas lingkungan. Reklamasi dapat dilaksanakan setelah mendapat perizinan meliputi izin lokasi dan izin pelaksanaan reklamasi. Penentuan lokasi dilakukan berdasarkan Rencana Zonasi Wilayah Pesisir dan PulauPulau Kecil (RZWP3K) Provinsi, Kabupaten/Kota dan /atau Rencana Tata Ruang Wilayah (RTRW) Nasional, Provinsi, Kabupaten/Kota. Pentuan lokasi dilakukan berdasarkan pertimbangan aspek teknis, lingkungan hidup, sosial dan ekonomi. ${ }^{4}$ Sedangkan permohonan izin pelaksanaan dilengkapi dengan izin lokasi, rencana induk reklamasi, izin lingkungan, dokumen studi kelayakan teknis dan ekonomi finansial, dokumen rancangan detail reklamasi, dan bukti kepemilikan dan/atau penguasaan lahan. Izin pelaksanaan reklamasi diberikan selama lima tahun dan dapat diperpanjang maksimal lima tahun. Izin pelaksanaan reklamasi dapat dicabut bila tidak sesuai dengan perencanaan reklamasi dan dicabutnya izin lingkungan. Pelaksanaan reklamasi harus memperhatikan keberlanjutan kehidupan dan penghidupan masyarakat, keseimbangan antara pemanfaatan dan kepentingan pelestarian fungsi lingkungan pesisir

4 Aspek teknis meliputi hidrooceanografi (pasang surut, gelombang, dan sedimen dasar laut), hidrologi (curah hujan, air tanah, debit air sungai/saluran, dan air limpasan), batimetri (kontur kedalaman dasar perairan), topografi (kontur permukaan daratan), geomorfologi (bentuk dan tipologi pantai), dan geoteknik (sifat-sifat fisis dan mekanisme lapisan tanah).

Aspek lingkungan hidup berkaitan dengan kualitas air laut,air tanah, udara, kondisi ekosistem pesisir (mangrove, lamun, terumbu karang), flora dan fauna darat, dan biota perairan.

Aspek sosial ekonomi berkaitan dengan demografi (jumlah penduduk, pendapatan, mata pencaharian, pendidikan, kesehatan, keagamaan), akses publik (jalan dan jalur transportasi, informasi, dan pembangunan reklamasi), dan potensi relokasi (lahan relokasi, fasilitas sarana dan prasarana). 
Vol.4, No.1, April 2018

dan pulau-pulau kecil, serta persyaratan teknis pengambilan, pengurugan, dan penimbunan material.

\section{METODOLOGI}

Penelitian yang di lakukan ini menggunakan metode penelitian dengan metode kualitatif. Pendekatan kualitatif berguna untuk menghasilkan uraian yang mendalam tentang ucapan, tulisan, dan perilaku yang dapat diamati dari suatu individu kelompok masyarakat, dan organisasi dalam suatu konteks tententu yang dikaji dari sudut pandang yang utuh, komprehensif, dan holistik. Penelitian kualitatif merupakan metode pengumpulan dan analisa datanya bersifat non kuantitatif dengan tujuan untuk mengeksplorasi hubungan sosial dan deskripsi realitas yang dialami respon (Saraclaers, 1993:6). Untuk keperluan penelitian ini, peneliti memilih menggunakan tipe penelitian deskriptif analitik agar langkah pokok sebuah sebuah penelitian yaitu deskripsi objek penelitian dapat dirumuskan sehingga mempermudah fase selanjutnya yaitu melakukan analisa mendalam dan komprehensif tentang objek yang didalamnya tidak dimaksudkan untuk menguji hipotesis, akan tetapi hanya menggambarkan apa danya tentang variabel, gejala atau keadaan dan melakukan analisis atas fakta untuk dijadikan pedoman di masa mendatang.

Menurut Whitney, metode deskriptif adalah pencarian fakta dengan interpretasi yang tepat (Whitney dalam Nazir, 2003: 54). Penelitian deskriptif mempelajari masalah-masalah dalam masyarakat, serta tata cara yang berlaku dalam masyarakat serta situasi-situasi tertentu, termasuk hubungan, kegiatan-kegiatan, sikap-sikap, pandangan-pandangan, serta prosesproses yang sedang berlangsung dan pengaruh-pengaruh dari suatu fenomena. Dalam penelitian kuantitatif, peneliti akan menggunakan instrumen untuk mengumpulkan data, sehingga dalam penelitian kualitatif peneliti akan lebih banyak menjadi instrument. Sebab, dalam penelitian kualitatif, peneliti merupakan key instruments. Instrumen penelitian digunakan untuk mengukur nilai variabel yang diteliti. Dengan demikian jumlah instrumen yang akan digunakan untuk penelitian akan tergantung pada jumlah variabel yang diteliti.

Pengumpulan data adalah suatu langkah pokok dalam suatu penelitian karena sangat menentukan variabel yang diperlukan dalam pengukuran. Untuk itu, penyusunan instrumen pengumpulan data harus ditangani secara serius dan sistematik. Dalam penelitian ini, pengumpulan data yang digunakan antara lain observasi, indepth interview, dan studi pustaka 


\section{HASIL PENELITIAN}

Manajemen konflik adalah proses pihak yang terlibat konflik dan pihak ketiga menyusun strategi konflik dan menerapkannya untuk mengendalikan konflik agar menghasilkan resolusi konflik yang diinginkan. Reklamasi Pantai Utara Jakarta merupakan urusan pemerintahan konkruen dimana terjadi pelimpahan kekuasaan dari Pemerintah Pusat kepada Gubernur dengan asas dekonsentrasi. Periode yang diteliti oleh peneliti dimulai pada tahun 2015 sampai dengan tahun 2016 karena konflik reklamasi Pulau G muncul ketika dikeluarkannya surat izin pelaksanaan reklamasi Pulau G Pantai Utara yaitu SK Gubernur Provinsi DKI Jakarta Nomor 2238 Tahun 2014 pada 23 Desember 2014. Pada saat itu, muncul berbagai lembaga swadaya masyarakat yang terorganisir dan membentuk Koalisi Selamatkan Teluk Jakarta. Koalisi tersebut menyuarakan aspirasi masyarakat dan bersama masyarakat Muara Angke mengajukan gugatan melalui Pengadilan Tata Usaha Negara. Hal tersebut mendorong pemerintah pusat untuk melakukan tindakan dengan membentuk Komite Bersama Reklamasi Pantai Utara Jakarta.

\section{Reklamasi Pantai Utara Jakarta}

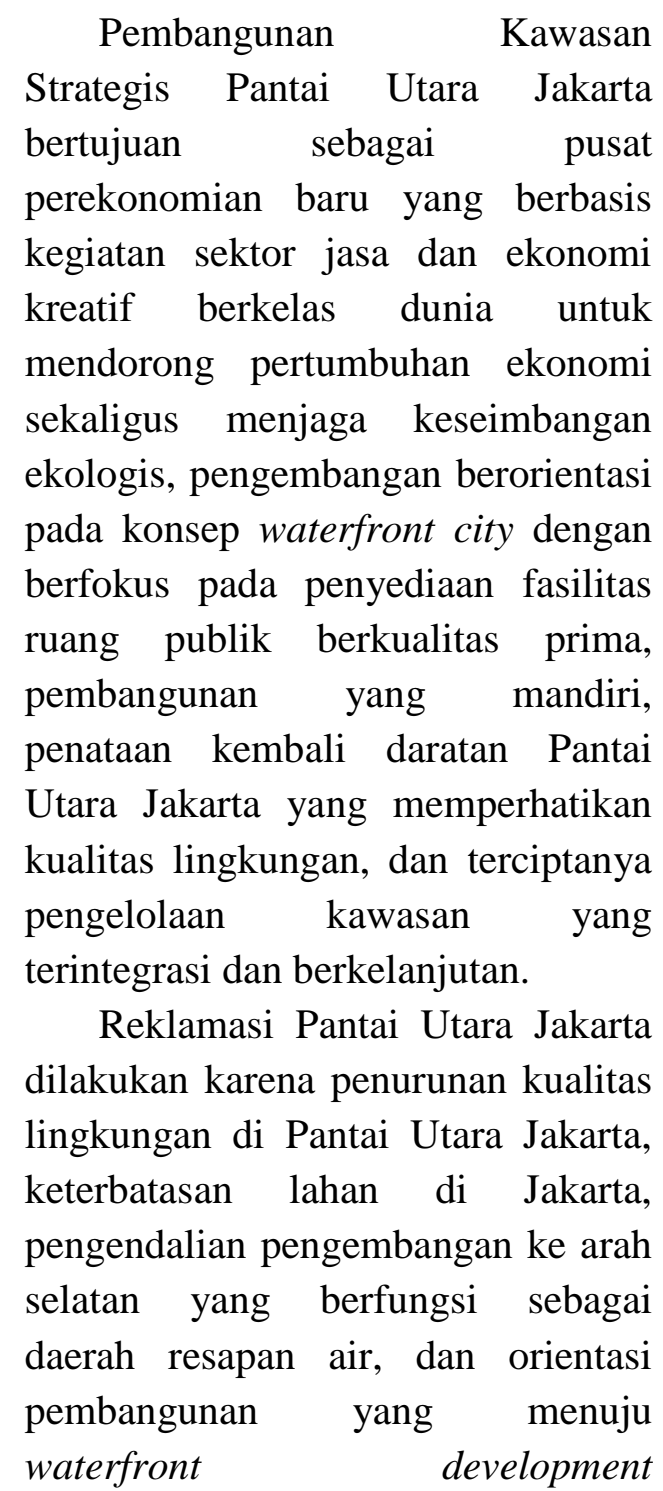
(pembangunan tepi laut). Gagasan untuk mewujudkan waterfront development dilakukan melalui reklamasi dan revitalisasi Pantai Utara Jakarta dan meningkatkan kualitas lingkungan daratan (pantai lama) dengan mekanisme subsidi silang.

Subsidi silang terdiri dari kewajiban, kontribusi lahan, dan penambahan kontribusi dari pengembang Pulau Reklamasi. Kewajibannya adalah menyediakan 
prasarana, sarana, dan utilitas dasar yang dibutuhkan oleh setiap pulau, menyediakan infrastruktur penghubung antar pulau, dan melakukan pengerukan sedimentasi kanal lateral dan vertikal secara berkala. Kontribusi lahan untuk Pemerintah Provinsi DKI Jakarta sebesar 5\% dari lahan masingmasing pulau reklamasi. Kemudian, tambahan kontribusi pengembang berupa penataan kembali kawasan utara Jakarta secara umum.

Terdapat beberapa dokumen perencanaan ruang untuk kawasan pesisir Jakarta. Pertama, Rencana Tata Ruang Wilayah (RTRW) 2030 yang mengatur seluruh wilayah Jakarta termasuk struktur ruang dan ketentuan umum zonasi. Kedua, Rencana Detail Tata Ruang (RDTR) Kawasan Strategis Pantai Utara Jakarta dan Rencana Zonasi yang mengatur seluruh wilayah administrasi Jakarta meliputi strultur skala tersier (kecamatan dan keluaran) dan detail peraturan zonasi kecuali reklamasi 17 pulau Pantai Utara. Ketiga, Rencana Tata Ruang (RTR) Kawasan Strategis Pantai Utara Jakarta mengatur kawasan reklamasi 17 pulau dan dari pantai lama sampai dengan kedalaman -8 meter, struktur primer dan sekunder, dan detail peraturan zonasi.Keempat, Rencana Zonasi Wilayah Pesisir dan Pulau-Pulau Kecil yang mengatur pembagian alokasi ruang perairan, kebijakan, strategi, dan arahan pengembangan setiap zona perairan, dan kegiatan yang boleh dan tidak boleh dilakukan dalam setiap zona.

Kawasan Pantai Utara Jakarta akan direklamasi seluas 5.218 hektare yang terdiri dari 17 pulau. Secara keseluruhan, perairan tersebut berbatasan dengan garis Pantai Utara Jakarta \pm 32 kilo meter. Secara geografis, Pantai Utara Jakarta berbatasan dengan: bagian barat dengan Pantai Utara Kabupaten Tanggerang, bagian timur

\section{Fase Potensi Konflik}

Fase yang pertama adalah fase potensi konflik. Fase ini terdiri dari sumber-sumber konflik, asal-usul terjadinya konflik, dan belum terorganisirnya pihak yang berkonflik. Pada fase potensi konflik, tipe konflik yang terjadi adalah tipe konflik laten walaupun reklamasi Pulau C dan D sudah dilakukan sebelum reklamasi Pulau G. Terdapat beberapa temuan dalam memetakan fase potensi konflik. Pertama, masyarakat Muara Angke pada umumnya tidak mengetahui apakah maksud, tujuan, dan dampak reklamasi bagi masyarakat terutama masyarakat yang bermatapencaharian sebagai nelayan yang mencari ikan di Pantai Utara Jakarta. Kedua, masyarakat terdampak tampaknya juga tidak dilibatkan dalam pembahasan tentang reklamasi, tetapi yang diikutkan hanya pemilik kapal dan tokoh masyarakat. Ketiga, nelayan mengetahui dampak reklamasi terhadap hasil tangkapan 
Vol.4, No.1, April 2018

mereka tetapi tidak mengetahui apa yang hendak dilakukan karena pada saat itu tidak terdapat wadah perhimpunan nelayan di Muara Angke. Sumber konflik pada penelitian ini terbagi menjadi dua yaitu sumber internal dan sumber eksternal. Sumber internal adalah konflik yang berasal dari masyarakat
Muara Angke dan Pemerintah Provinsi DKI Jakarta sedangkan sumber eksternal berasal dari luar masyarakat Muara Angke dan Pemerintah Provinsi DKI Jakarta.

Adapun gambaran mengenai fase potensi konflik, peneliti gambarkan melalui diagram berikut:

\section{Gambar 1.Fase Potensi Konflik}

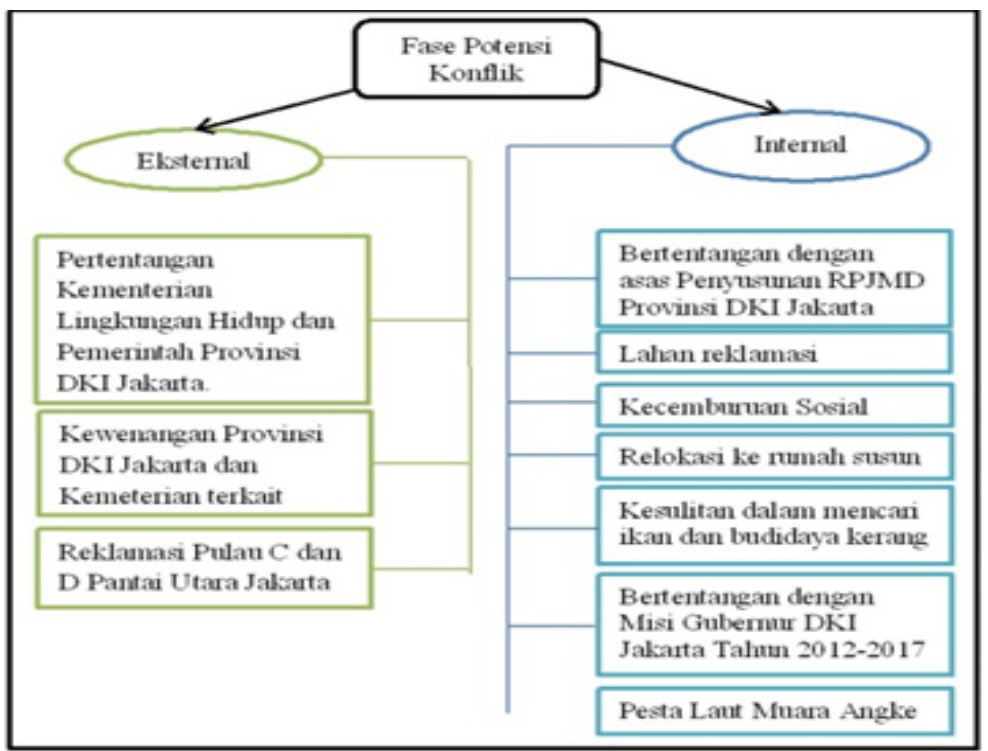

\begin{abstract}
Reklamasi Pantai Utara
Jakarta merupakan urusan pemerintahan konkruen dimana terjadi pelimpahan kekuasaan dari Pemerintah Pusat kepada Gubernur dengan asas dekonsentrasi. Menurut Farid $^{5}$, reklamasi berasal dari kata "re" dan "claim" yang berarti menyatakan kembali. reklamasi ini pertama dilakukan di Belanda karena
\end{abstract}

5 Apatur Kementerian Lingkungan Hidup dan Kehutanan Republik Indonesia. Diwawancarai pada 14 Agustus 2017. pulau mereka terendam oleh air. Oleh karena itu, penimbunan dilakukan untuk mengembalikan daratan yang terendam tersebut. berbeda dengan kondisi Pantai Utara Jakarta yang dari dahulu merupakan pantai bukan daratan. Oleh karena itu, tidak tepat bila reklamasi dilakukan di Pantai Utara Jakarta.

Pada tahun 1995, terbitlah Keputusan Presiden Nomor 52 Tahun 1995 Tentang Reklamasi Pantai Utara Jakarta. Kebijakan 
Vol.4, No.1, April 2018

tersebut seakan tidak dipertentangkan berbagai pihak. Mengutip yang disampaikan oleh Ismail $^{6}$ yang mengatakan bahwa: "reklamasi adalah perbaikan Pantai Utara Jakarta. Dananya waktu itu 100 juta. Indonesia sudah memiliki banyak pulau, masa mau bangun pulau lagi? Reklamasi memancing kejahatan di Indonesia, masyarakat Muara Angke tidak setuju dengan reklamasi. Reklamasi pada zaman Pak Harto adalah perbaikan Pantai Utara bukan reklamasi seperti saat ini."

Berbeda dengan pernyataan Ismail, Kementerian Lingkungan Hidup memberikan respon terhadap Keputusan Presiden tersebut dengan membentuk Komisi Penilai AMDAL pada tahun 1996. Kemudian pada tahun 1999, kajian Komisi Penilai AMDAL menyatakan bahwa reklamasi Pantai Utara Jakarta membutuhkan 330 juta kubik material pasir. Akan tetapi pada saat itu, Pemerintah Pusat tidak merespon pernyataan Komisi Penilai AMDAL tersebut. Komisi ini terus melakukan kajian sampai akhirnya pada tahun 2002 ditemukan bahaya dari adanya reklamasi bagi kelangsungan ekosistem dan dampak bagi masyarakat sekitar terutama nelayan.

6 Masyarakat Muara Angke yang dahulu berprofesi sebagai nelayan. Akan tetapi sudah cukup tua sehingga memutuskan untuk pensiun sebagai nelayan. Diwawancarai pada 23 Agustus 2017
Oleh karena itu, Kementerian Linkungan Hidup mengeluarkan Surat Keputusan Menteri Lingkungan Hidup Nomor 14 Tahun 2003 Tentang Ketidaklayakan Rencana Kegiatan Reklamasi dan Revitalisasi Pantai Utara.

Surat Keputusan tersebut diajukan banding melalui Pengadilan Tata Usaha Negara (PTUN) oleh Pengembang pulau reklamasi Pantai Utara Jakarta dan dimenangkan oleh pengembang. Kemudian, Kementerian Lingkungan Hidup melakukan banding ke PTUN tetapi masih dimenangkan oleh pengembang. Usaha Kementerian Lingkungan Hidup tidak berhenti, kasasi diajukan kepada Mahkamah Agung (MA) dan diterima. Kemudian, pengembang melakukan peninjauan kembali terhadap kasasi yang diterima oleh MA. Peninjauan Kembali kasasi diterima dan terdapat beberapa keputusan MA. Pertama, memperbaharui AMDAL yang telah diajukan pada tahun 2003. Kedua, pembuatan KLHS bersama dengan Pemerintah Daerah di sekitar Pantai Utara Jakarta. Ketiga, Menteri Negara sebagai tim pengarah yang bertugas mengarahkan Badan Pengendali Reklamasi Pantai Utara Jakarta (Gubernur Provinsi DKI Jakarta) tidak memiliki kewenangan untuk membatalkan reklamasi. Keempat, Presiden Republik Indonesia memiliki hak untuk memberhentikan reklamasi apabila 
Vol.4, No.1, April 2018

terdapat kelemahan dalam Penyusunan AMDAL.

Dalam penyusunan AMDAL, pembahasan dilakukan masingmasing Pulau Reklamasi dengan Pemerintah Provinsi DKI Jakarta (Komisi Penilai AMDAL dari Dinas Lingkungan Hidup Provinsi DKI Jakarta) sehingga AMDAL terpadu pulau A-Q tidak ada. Dalam Reklamasi Pulau G kajian dilakukan antara Pemerintah Provinsi DKI Jakarta dan PT. Muara Wisesa Samudra. Dalam kajian AMDAL, masyarakat Muara Angke yang terkena dampak khususnya nelayan tradisional dilibatkan.

Hal ini bertentangan dengan asas penyusunan RPJMD yang tercantum dalam Peraturan Daerah Provinsi DKI Jakarta Nomor 2 Tahun 2013 Tentang Rencana Pembangunan Jangka Menengah Daerah Tahun 2013-2017. Pertama, asas demokrasi berkaitan dengan penyelenggaraan pembangunan dengan pendekatan dari, oleh, dan untuk kepentingan masyarakat. Kedua, transparansi. Transparansi berkaitan dengan memberikan kesempatan bagi masyarakat berpartisipasi dalam pembangunan dengan memberikan informasi yang benar, jelas, dan jujur. Ketiga, asas berwawasan lingkungan berkaitan dengan pengelolaan sumbedaya secara bijaksana dan berkesinambungan untuk meningkatkan mutu masyarakat. Lokasi reklamasi Pulau G terdapat ovjek vital nasional yaitu pertukaran air panas dan air dingin untuk menunjang kinerja PLTU Muara Karang, membuat air menjadi keruh sehingga nelayan kesulitan mencari ikan, dan berdampak pada daerah tempat pengambilan material reklamasi Pulau $G$ yang berada di Teluk Lontar, Serang. Selain bertentangan dengan asas penyusunan RPJMD, reklamasi Pantai Utara Jakarta yang merupakan perwujudan dari misi pertama Pemerintah Provinsi DKI Jakarta tahun 2012-2017 juga bertentangan dengan misi yang lainnya. Misi kedua berkaitan dengan Jakarta bebas dari masalah menahun seperti permukiman kumuh dan sampah. Misi ketiga berkaitan dengan ketersediaan hunian dan ruang publik yang layak serta terjangkau bagi warga kota serta misi keempat berkaitan dengan membangun budaya yang toleran. Ada dugaan dengan dilaksanakannya reklamasi, menurut banyak pihak akan menimbulkan kecemburuan sosial antara Masyarakat Muara Angke dan etnis Tionghoa.

\section{Fase Pertumbuhan Konflik}

Pada fase pertumbuhan konflik, konflik sudah terorganisir dan terbentuknya kelompokkelompok di masyarakat. Kelompok tersebut berinteraksi terhadap ketidaksepakatan dengan individu atau kelompok yang lainnya. Pada fase ini, konflik yang awalnya laten sudah menjadi konflik terbuka 
Vol.4, No.1, April 2018

karena permasalahan reklamasi Pulau G Pantai Utara Jakarta sudah terangkat ke permukaan, berakar, nyata, dan memerlukan tindakan untuk mengatasi akar, penyebab, dan dampaknya. Pada fase ini muncul kelompok-kelompok yang berempati terhadap dampak yang dirasakan masyarakat yang bermata pencaharian sebagai nelayan tradisional. Kelompok tersebut melakukan sosialisasi di kawasan abu-abu Muara Angke. Untuk memberikan gambaran mengenai fase pertumbuhan konflik terkait reklamasi Pulau G Pantai Utara Jakarta,

\section{Gambar 2. Fase Pertumbuhan Konflik}

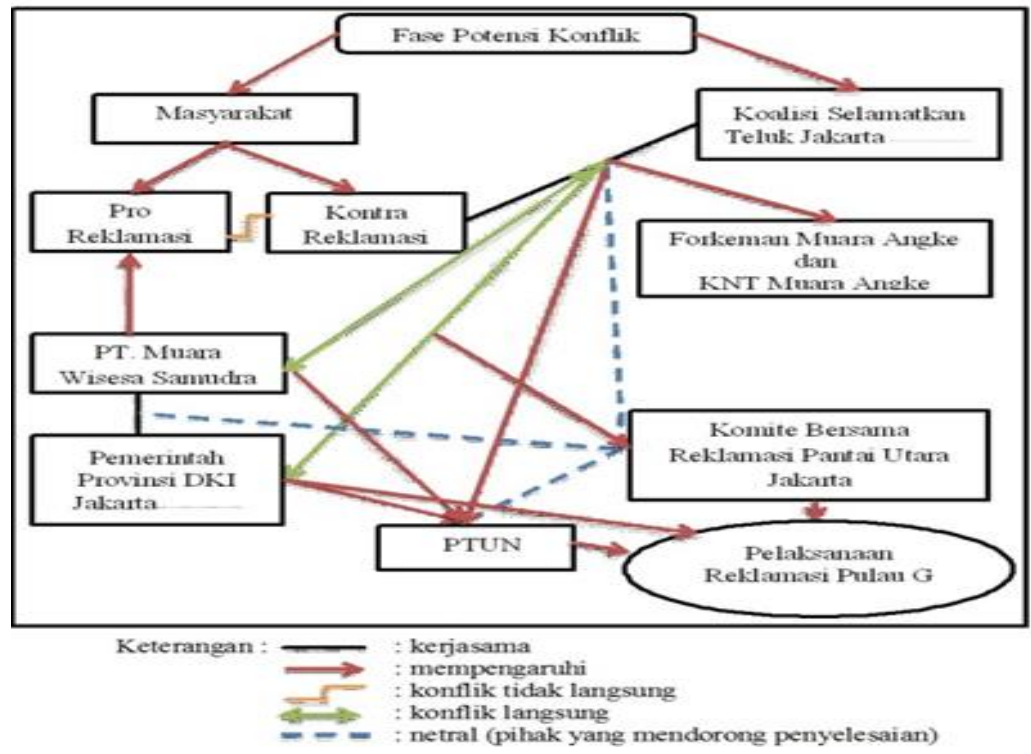

Setelah dikeluarkannya Surat Keputusan Gubernur Provinsi DKI Jakarta Nomor 2238 Tahun 2014 Tentang Pemberian Izin Pelaksanaan Rekalamasi Pulau G Pantai Utara Jakarta kepada PT. Muara Wisesa Samudra pada tanggal 23 Desember 2014, banyak kalangan yang berfokus pada masalah reklamasi. Padahal reklamasi pulau $\mathrm{C}$ dan D SUDAH
DILAKUKAN Lebih dahulu pada tahun 2012. Martin ${ }^{7}$ mengatakan bahwa:

"Reklamasi Pulau G menjadi fokus KNTI mulai dari tahun 2014 karena waktu itu nelayan kami (anggota KNTI) berkonflik dengan Pulau G yang merupakan lokasi nelayan mencari ikan. Reklamasi merupakan kasus lama yang sudah banyak ditolak oleh pemerintah terutama pemerintah

Ketua DPP Kesatuan Nelayan Tradisional Indonesia (KNTI) yang diwawancarai pada 10 Agustus 2017 
Vol.4, No.1, April 2018

pusat (Kementerian Lingkungan Hidup dan Kehutanan). Akan tetapi, tetap saja dijalankan."

Pihak yang menolak reklamasi berargumen bahwa partisipasi masyarakat adalah partisipasi manipulatif. Hal ini dikarenakan masyarakat hanya diikutkan pada fase-fase terakhir pada saat mau disahkan. Adapun yang menyetujuinya adalah tokoh masyarakat yang sudah mendapatkan bantuan dari pengembang sehingga tidak objektif melihatnya bahkan diindikasikan adanya suap. Selain itu, informan juga mengatakan bahwa reklamasi adalah perampasan laut sama dengan membiarkan kerusakan terjadi dan merampas untuk kepentingan komersial dimana terdapat beberapa alasan terkait pernyataannya tersebut. Pertama, tidak melalui konsultasi publik sehingga masyarakat tidak mengetahui adanya proyek beserta dampaknya bagi masyarakat. Kedua, dampak buruknya tidak hanya di Pulau G saja, tetapi di daerah tempat pengambilan material reklamasi. Ketiga, Teluk Jakarta memang sudah kritis, ketika di reklamasi akan semakin kritis.

Selain KNTI, Lembaga Bantuan Hukum Jakarta juga ikut melakukan pendampingan hukum terkait Reklamasi Pulau G Pantai Utara Jakarta sejak tahun 2014. Lembaga Swadaya masyarakat ini awalnya berdiri masing-masing, tetapi akhirnya tetrbentuk dalam suatu koalisi yang bernama Koalisi Selamatkan Teluk Jakarta. Koalisi dibentuk untuk menyatukan gerakan agar lebih representatif dan terfokus. Kemunculan koalisi ini me Adanya LSM di Muara Angke tidak diterima semua kalangan masyarakat. Misalnya ketua RW 01 yang mengatakan bahwa LSM memperkeruh suasana. Pernyataan Ketua RW 01 ini diperkuat dengan pernyataan Warnita $^{8}$ yang mengatakan bahwa:

"pada awalnya warga Muara Angke tidak ada pro dan kontra terkait reklamasi, tetapi dengan munculnya LSM seperti Walhi dan KNTI mengajak orang-orang yang memiliki kepentingan pribadi seperti uang dan lain-lain sehingga masyarakat terpecah belah menjadi pro dan kontra. Timbul saling fitnah dimana yang pro dikatakan dapat uang dan yang kontra dibilang mereka butuh duit. Ia juga mengatakan bahwa ia pernah dikeroyok dan diminta untuk tidak mendukung reklamasi. saat ini ada 20 orang dari KNT (Komunitas Nelayan Tradisional Muara Angke), dua orang PNPII (Paguyuban Nelayan Pengolah Ikan Indonesia), dan dua orang masyarakat Muara Angke."

mberikan dorongan untuk terbentuknya lembaga swadaya masyarakat di Muara Angke.

Pertentangan antara masyarakat dan Pemerintah Provinsi DKI Jakarta membuat Presiden mengambil langkah tegas untuk menyelesaikan permasalahan Reklamasi Pantai Utara Jakarta. Presiden memerintahkan dan mengarahkan Menteri Koordinator Kemaritiman untuk menyelesaikan masalah reklamasi Pantai Utara Jakarta pada tahun 2016. Terdapat empat arahan Presiden yaitu tidak merusak lingkungan, nelayan tidak dirugikan, sesuai aturan, dan terintegrasi $\mathrm{NCICD}^{9}$.

\footnotetext{
${ }^{8}$ Nelayan Muara Angke yang diwawancarai pada 7 Juli 2017

9 NCICD (National Capital Integrated Coastal Development) adalah program kerjasama
} 
Vol.4, No.1, April 2018

Merespon hal tersebut, Menteri Koordinator Kemaritiman membentuk Komite Bersama Reklamasi Pantai Utara Jakarta pada 18 April 2016 terdiri dari Kementerian Lingkungan Hidup dan Kehutanan, Kementerian Perhubungan, Kementerian Kelautan dan Perikanan, dan Pemerintah Provinsi DKI Jakarta. Kementerian Lingkungan Hidup dan Kehutanan berfokus pada review AMDAL Reklamasi Pantai Utara Jakarta yang diselesaikan oleh Komisi Penilai AMDAL Provinsi DKI Jakarta pada tahun 2012.

Berdasarkan Undang-Undang Nomor 27 Tahun 2007 Tentang Pengelolaan Wilayah Pesisir dan Pulau-Pulau Kecil, Peraturan Presiden Nomor 122 Tahun 2012 Tentang Reklamasi di Wilayah Pesisir dan Pulau-Pulau Kecil, dan Peraturan Menteri Kelautan dan Kementerian Kelautan dan Perikanan Nomor 17 Tahun 2013 Tentang Perizinan Reklamasi di Wilayah Pesisir dan PulauPulau Kecil, KKP memiliki kewenangan dalam reklamasi. Akan tetapi, dalam kebijakan reklamasi Pantai Utara Jakarta KKP tidak dilibatkan. Walaupun demikian, Pemerintah Provinsi DKI Jakarta tidak dapat disalahkan karena kewenangan Reklamasi Pantai Utara Jakarta berada pada Pemerintah Provinsi (Gubernur) DKI Jakarta berdasarkan Keputusan Presiden Nomor 52 Tahun 1995 tidak pernah dicabut. Kementerian

Pemerintah Pusat, Pemerintah Provinsi DKI Jakarta, Pemerintah Provinsi Banten, dan Pemerintah Provinsi Jawa Barat yang dikoordinator oleh Menteri Koordinator Kemaritiman. NCICD belum memiliki payung hukum formal tetapi pelaksanaannya harus direncanakan secara sinergis agar sinergis dan komplenter dengan Reklamasi Pantai Utara Jakarta. Karena berada dalam lokasi yang sama
Kelautan dan Perikanan berfokus pada stakeholder yaitu nelayan. Dalam reklamasi Pantai Utara Jakarta, Kementerian hanya dapat mengawal dan memberi pendapat terhadap keputusan yang disampaikan kepada Menteri Koordinator Kemaritiman sebagai Koordinator Komite Bersama Reklamasi Pantai Utara Jakarta. Pada fase pertumbuhan konflik, para aktor saling melakukan tugasnya dengan mempengaruhi, bekerjasama, bertentangan, dan netral tergantung pada tujuan yang hendak dicapainya.

\section{Fase Pemicu dan Ekskalasi Konflik}

Pada fase ini, konflik semakin terlihat dan terdapat keinginan untuk melakukan tindakan koersif. Tindakan koersif adalah tindakan sosial untuk memaksa pihak lawan untuk melakukan hal yang tidak diinginkan olehnya. Pada tahap ini, masing-masing pihak melakukan intimidasi dan negosiasi. Bila dilihat dari konsepsi Durkheim ${ }^{10}$ tentang pembagian masyarakat, dalam kasus konflik reklamasi Pantai Utara Jakarta, masyarakat Muara Angke termasuk dalam masyarakat mekanik sehingga hal yang dilakukan didasarkan pada kesadaran koletif yang mengikat individu.

10 Masyarakat dibagi menjadi masyarakat mekanik dan masyarakat organik. Masyarakat mekanik adalah masyarakat yang bergerak didasarkan kesadaran kolektif dan kesaadaran umum, sedangkan masyarakat organik adalah individu-individu yang terhubung karena suatu kebutuhan. 
Vol.4, No.1, April 2018

Gambar 3. Fase Pemicu dan Ekskalasi Konflik (1)

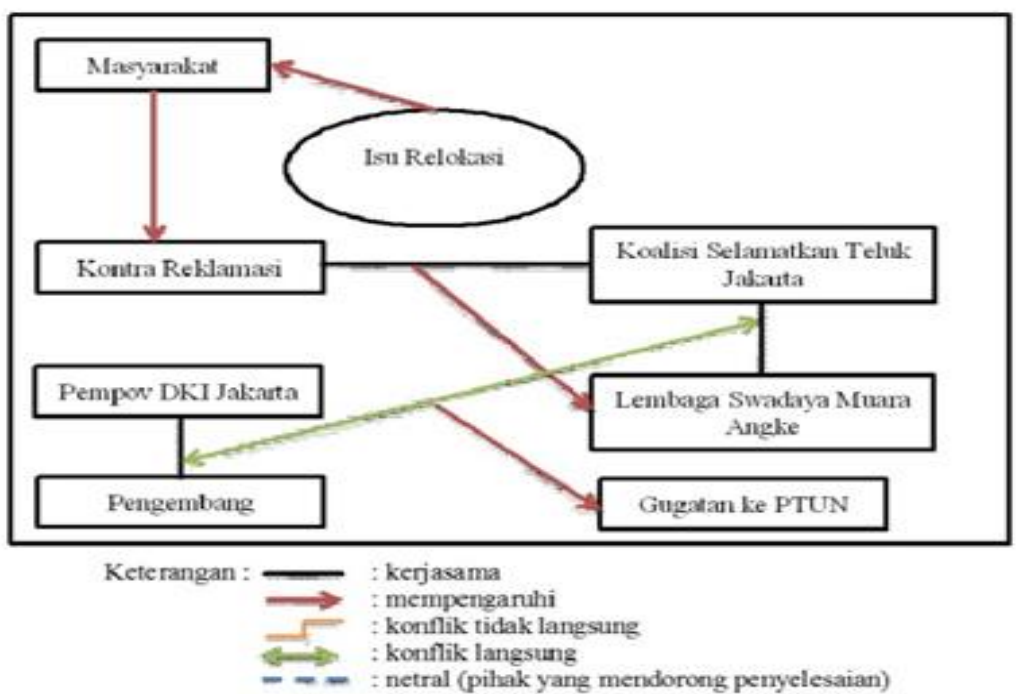

Masyarakat Muara Angke mulai bergerak untuk menolak reklamasi sejak adanya isu bahwa warga Muara Angke akan dipindahkan ke Kepulauan Seribu. Dengan kehadiran Koalisi Selamatkan Teluk Jakarta mendorong masyarakat untuk membentuk organisasi kemasyarakatan seperti Forum Komunikasi Nelayan (Forkeman) Muara Angke, Komunitas Nelayan Tradisional (KNT) Muara Angke, dan Paguyuban Nelayan Pengolah Ikan (PNPI). Selain itu, mendukung masyarakat untuk menggugat Surat Keputusan Gubernur DKI Jakarta yang memberikan izin pelaksanaan reklamasi Pulau G Pantai Utara Jakarta kepada PTUN. Gugatan diajukan pada 25
Oktober 2015. Terdapat beberapa gugatan yang diajukan berdasarkan Putusan PTUN Nomor 193/G/LH/2015/PTUN-JKT yaitu meningkatkan banjir di Jakarta dan operasional objek vital nasional; pencematan ekosistem laut hilir, sedimentasi, dan penurunan kualitas air; potensi konflik antar masyarakat tradisional di Pesisir Pantai Utara Jakarta; pertumbuhan terumbu karang di Kepulauan Seribu akan terganggu; kerusakan lingkungan yang lebih parah karena mengubah ekosistem dan menghilangkan sumberdaya kelautan dan perikanan yang menjadi matapencaharian penggugat. Gugatan tersebut dimenangkan oleh

PTUN. 
Vol.4, No.1, April 2018

\section{Gambar 4. Fase Pemicu dan Ekskalasi Konflik (2)}



Isu pemindahan ke Kepulauan Seribu semakin jelas dan penduduk yang akan direlokasi adalah masyarakat yang tinggal di pinggir Sungai Kali Adem. Untuk mengurangi penolakan dari masyarakat, pengembang melakukan pendekatan dengan membuka lapangan berupa pembangunan pulau reklamasi yang pekerjanya diprioritaskan untuk masyarakat Muara Angke; meningkatkan objek wisata; bantuan pembangunan masjid, musholla, pemberangkatan umroh tokoh nelayan, dan dana koperasi; melakukan pengurukan; dan pembuatan sertifikat tanah di Muara Angke. Namun disisi lain, masyarakat harus memperhatikan kemungkinan adanya kecemburuan sosial terhadap etnis tertentu dan penyelundupan barang terlarang seperti narkoba yang sebelumnya pernah terjadi dari Kepulauan Seribu.

\section{Fase Pasca Konflik}

Pada fase ini, konflik sudah kembali turun dan masing-masing pihak membangun kembali hubungan damai dan berkomunikasi. Gase ini dilakukan dengan rekonstruksi sosial, politik, ekonomi, dan pembangunan kembali hubungan antar kelompok. Reklamasi memberikan dampak domino yaitu perempuan kesulitan mengelola ekonomi keluarga karena penghasilan menurun dan anak-anak terancam putus sekolah. Terdapat konflik horizontal dan vertikal. Konflik horizontal adalah terjadi antara masyarakat yang pro reklamasi dan kontra reklamasi. sedangkan konflik vertikal adalah konflik yang terjadi antara pemerintah pusat maupun pemerintah provinsi DKI Jakarta dan masyarakat nelayan tradisional Muara Angke. Berdasarkan temuan di lapangan, reklamasi Pantai Utara Jakarta tidak memenuhi ketentuan putusan kasasi MA yang dimenangkan Pemerintah Provinsi DKI Jakarta dan pengembang yaitu enam isu pokok reklamasi yang diajukan oleh Kementerian Lingkungan Hidup. 
Vol.4, No.1, April 2018

Tabel 1. Kelengkapan Analisis Dokumen AMDAL Berdasarkan 6 Kriteria Kementerian Lingkungan Hidup (2003)

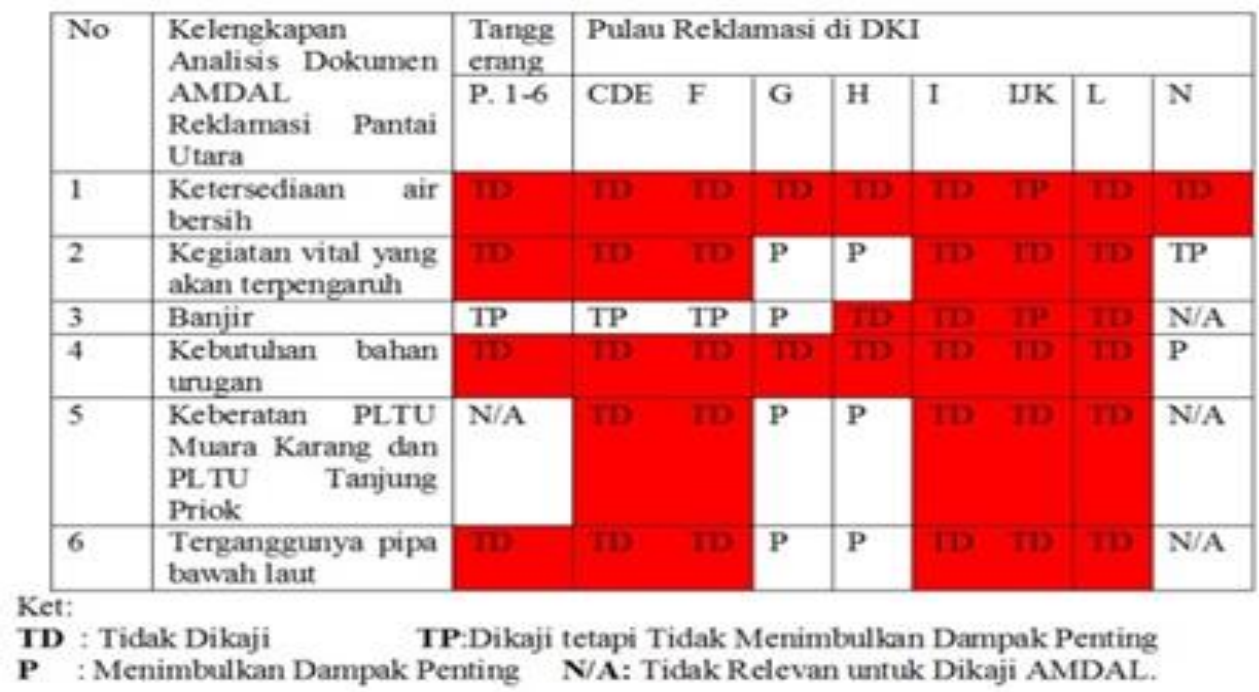

Sumber : Kementerian Lingkungan Hidup dan Kehutanan Tentang Reklamasi Pantai Utara Jakarta

Berdasarkan tabel tersebut, reklamasi Pulau G memiliki dampak penting terhadap kegiatan vital, ketersediaan air bersih, banjir, keberatan PLTU Muara Karang dan PLTU Tanung Priok. Berdasarkan pertimbangan tersebut, Kementerian Lingkungan Hidup dan Kehutanan menggunakan kewenangannya sebagai Second Line Enforcement ${ }^{11}$. Miftahul ${ }^{12}$ menambahkan bahwa:

"Kementerian Lingkungan
Hidup dan Kehutanan

11 Second Line Enforcement adalah penegakan hukum lapis kedua yang dilakukan menteri terhadap kegiatan yang izin lingkungannya diterbitkan Pemerintah Daerah apabila dianggap terdapat pelanggaran serius terhadap perlindungan dan pengelolaan lingkungan hidup.

12 Aparatur Kementerian Lingkungan Hidup dan Kehutanan yang diwawancarai pada 3 Agustus 2017 memberikan sanksi administrasi berdasarkan Undang-Undang Nomor 32 Tahun 2009 Tentang Perlindungan dan Pengelolaan Lingkungan Hidup Pasal 76 ayat (2) yaitu paksaan pemerintah dan pasal 80 ayat (1f) yaitu penghentian sementara seluruh kegiatan. Menteri Lingkungan Hidup dan Kehutanan mengeluarkan

SK.355/Menlhk/Setjen/Kum.9/5/ 2016 Tentang Pengenaan Sanksi Administrasi Paksaan Pemerintah Berupa Penghentian Sementara Seluruh Kegiatan PT. Muara Wisesa Samudra pada pulau G di Pantai Utara Jakarta. SK tersebut dikeluarkan pada 10 Mei 2016.” 
Dalam pengenaan sanksi administratif, PT. Muara Wisesa Samudra harus memenuhi beberapa kewajiban. Pertama, menghentikan operasional kegiatan sampai dipenuhinya kewajiban pengembang. Kedua, melakukan perubahan dokumen lingkungan dan izin lingkungan Pulau $G$ atas ketidaksesuaian kegiatan sebagaimana tercantum di dalam dokumen lingkungan dan izin lingkungan paling lama 120 hari kalender mencakup perbaikan prediksi dampak, rencana menyeluruh reklamasi dan rencana peruntukan diatasnya dengan pertimbangan integrasi sosial; keterkaitan dengan rencana NCICD; mitigasi (mengurangi dampak bencana) sumber urug dan Kajian Lingkungan Hidup Strategis. Ketiga, memberikan data secara rinci mengenai sumber dan jumlah material pasir urug; batu; dan tanah yang digunakan paling lama 14 hari kalender. Keempat, melakukan kewajiban lain yang tercantum dalam izin lingkungan meliputi koordinasi dengan PT. PLN, PT. Nusantara Regas, dan PT. Pertamina Hulu Energi terkait pengawasan dan evaluasi bersama kinerja penggelaran material reklamasi; perbaikan metode dan teknik reklamasi dan perbaikan teknik penanggulangan sedimen paling lama 14 hari kalender; memperbaiki proses penerimaan tenaga kerja paling lama 30 hari kalender; sosialisasi rencana reklamasi Pulau G paling lama 30 hari kalender; pengukuran debit Kali Karang paling lama 7 hari kalender; dan pengukuran arah dan kecepatan arus serta kualitas air laut sesuai dengan koordinat titik pantau yang telah ditentukan dalam izin lingkungan paling lama 30 hari kalender. Kelima, membuat dan menyampaikan laporan pelaksanaan izin lingkungan paling lama 14 hari kalender. Keenam, melakukan upaya-upaya pengelolaan lingkungan hidup untuk mencegah terjadinya dampak lingkungan lebih lanjut selama berhentinya operasional seluruh kegiatan perusahaan.

Sampai saat ini, upaya yang dilakukan pemerintah untuk menanggulangi permasalahan reklamasi adalah dengan pemberhentian sementara Reklamasi Pulau G Pantai Utara Jakarta karena ketidaksesuaian dengan enam pokok bahasan reklamasi. Pelaksanaan reklamasi Pulau G Pantai Utara Jakarta saat ini hanya mendapatkan sanksi administratif sementara sehingga masih ada kemungkinan untuk dilanjutkan kembali. Namun berdasarkan observasi dan wawancara di lapangan, peneliti melihat bahwa kondisi pasca konflik terlihat dampak positif dan negatifnya. Dampak positifnya lebih oleh masyarakat nelayan tradisional sedangkan dampak negatifnya lebih dirasakan oleh pengembang. Terdapat beberapa dampak positif pemberhentian reklamasi Pulau G. 
Pertama, meningkatkan perekonomian nelayan karena hasil tangkapan nelayan baik bagi nelayan tradisional di Tanggul Kali Adem maupun Tempat Pelelangan Ikan sehingga istri nelayan dalam mengelola keuangan dan anaknya dapat bersekolah. Kedua, alur melaut tidak terganggu oleh aktivitas reklamasi dan mengakibatkan air tidak keruh. Ketiga, mengurangi kekhawatiran akan adanya peredaran dan penyelundupan obat terlarang seperti yang pernah terjadi di Kepulauan Seribu. Keempat, memberikan lapangan pekerjaan karena banyaknya hasil tangkapan di Pantai Utara Jakarta. Kelima, terbentuknya kerjasama antara Pemerintah Pusat dan Pemerintah Daerah terkait reklamasi. Keenam, memungkinkan terealisasinya pembuatan hutan mangrove di pesisir Pantai Utara Jakarta oleh Pemuda Komunitas Mangrove.

Selain itu, terdapat pula beberapa dampak negatifnya. Pertama, terganggunya alur kapal dan terjadi pendangkalan sehingga mengakibatkan karamnya kapal besar dan rusaknya mesin perahu kapal tradisional. Kedua, pemerintah dipandang tidak memberikan kepastian dalam berinvestasi. Ketiga, merugikan karena Pemerintah Provinsi memandang reklamasi ini memiliki banyak manfaat terutama untuk pertumbuhan ekonomi dan revitalisasi Pantai Utara Jakarta.

\section{KESIMPULAN}

Dalam fase potensi konflik, tipe konfliknya adalah konflik laten. Konflik bertipe laten karena masyarakat belum mengetahui apa itu reklamasi, fungsi, dan dampak tentang reklamasi Pulau G. Penyebabnya adalah tidak adanya sosialisasi yang dilakukan oleh pemerintah baik pusat dan daerah kepada Masyarakat Muara Angke. Pada fase pertumbuhan konflik, tipe konflik yang awalnya laten menjadi konflik terbuka karena pada fase ini masyarakat mengetahui apakah itu reklamasi, fungsi, dan dampaknya. Pemahaman masyarakat terkait reklamasi diberikan oleh Lembaga Swadaya Masyarakat (LSM) yang memfokuskan diri pada Reklamasi Pantai Utara Jakarta. Kehadiran LSM tersebut mendorong terbentuknya LSM di Muara Angke. Selain adanya LSM, Pemerintah Pusat pun berperan dalam menyelesaikan konflik yang terjadi dengan membentuk Komite Bersama Reklamasi Pantai Utara Jakarta. Pada fase pemicu dan ekskalasi konflik, konflik sudah mengarah kepada tindakan koersif dimana tiap kelompok digerakkan oleh kesadaran kolektif bergerak untuk melawan pihak yang bertentangan dengannya dengan melakukan gugatan dan demo. Pada fase pasca konflik, proses manajemen konflik dilakukan untuk mengurangi ekskalasi konflik untuk mengembalikan keadaan seperti sebelum terjadinya konflik. 
Manajemen konflik yang dilakukan adalah dengan diberikannya sanksi administratif paksaan pemerintah penghentian sementara kegiatan reklamasi Pulau G Pantai Utara Jakarta oleh Kementerian Lingkungan Hidup dan Kehutanan. Hal yang dapat dilakukan adalah dengan mengembalikan kepercayaan sesama masyarakat dan kepercayaan masyarakat terhadap pemerintah.

\section{DAFTAR PUSTAKA}

\section{Buku :}

Anggara, Sahya. (2013). Sistem Politik Indonesia. Bandung: CV. Pustaka Setia

Bungin, Burhan. (2010). Penelitian Kualitatif: Komunikasi, Ekonomi, Kebijakan Publik, dan Ilmu Sosial. Jakarta: Kencana Prenada Media Group.

Creswell, John W. (2014). Penelitian Kualitatif \&Desain Riset. Yogyakarta: PUSTAKA PELAJAR.

Forum Akademisi Papua Damai. (2012). Negosiasi "Noken Dialog untuk Papua Damai". Jakarta: Imparsial.

Ndraha, Taliziduhu. (2011). Kybernology: Ilmu Pemerintahan Baru I. Jakarta: PT. Rineka Cipta. Sara, La. (2014). Pengelolaan Wilayah Pesisir " Gagasan Memelihara Aset Wilayah Pesisir dan Solusi Pembangunan Bangsa". Bandung: Alfabeta.
Satori, Djam'an dan Aan Komariah. (2012). Metodologi Penelitian Kualitatif. Bandung: CV. ALFABETA.

Soemarwoto, Otto. (2003). Analisis Mengenai Dampak Lingkungan. Yogyakarta: Gadjah Mada University Press.

Soeroso. (2011). Praktik Hukum Acara Perdata: Tata Cara dan Proses Persidangan. Jakarta: Sinar Grafika

Sudjatmiko, Iwan Gargono. (2006). Gerakan Sosial: Wahana Civil Society bagi Demokratisasi. Jakarta: Pustaka LP3ES Indonesia.

Sugiyono. (2017). Metode Penelitian Kuantitatif, Kualitatif, dan R\&D. Bandung: ALFABETA,cv.

Surbakti, Ramlan. (2010). Memahami Ilmu Politik. Jakarta: PT. Grasindo

Susan, Novri. (2014). Pengatar Sosiologi Konflik. Jakarta: Prenamedia Group.

Winardi. (2007). Manajemen Konflik (Perubahan dan Pengembangan). Bandung: Mandar Maju.

Wirawan. (2013). Konflik dan Manajemen Konflik " Teori, Aplikasi, dan Penelitian”. Jakarta: Salemba Humantika.

\section{Sumber Peraturan:}

Undang-Undang Nomor 32 Tahun 2009 Tentang Perlindungan dan Pengelolaan Lingkungan Hidup. 
Undang-Undang Nomor 23 Tahun 2014 Tentang Pemerintahan Daerah

Keputusan Presiden Nomor 52 Tahun 1995 Tentang Reklamasi Pantai Utara Jakarta.

Keputusan Menteri Lingkungan Hidup dan Kehutanan Republik Indonesia Nomor: SK.355/Menlhk/Setjen/Kum.9/5/2 016.

Peraturan Daerah Provinsi Daerah Khusus Ibukota Jakarta No. 1 Tahun 2012 Tentang Rencana Tata Ruang Wilayah 2030.

Peraturan Daerah Provinsi Daerah Khusus Ibukota Jakarta No. 2 Tahun 2013 Tentang Rencana Pembangunan Jangka Menengah Daerah Tahun 2013-2017.

Peraturan Gubernur Provinsi Daerah Khusus Ibukota Jakarta No. 121 Tahun 2012 Tentang Penataan Ruang Kawasan Reklamasi Pantai Utara Jakarta.

Keputusan Gubernur Provinsi

Daerah Khusus Ibukota Jakarta Nomor 2238 Tahun 2014 Tentang Pemberian Izin Pelaksanaan Reklamasi Pulau G Kepada PT Muara Wisesa Samudra.

\section{Dokumen Instansi Pemerintahan:}

Analisis Mengenai Dampak Lingkungan Reklamasi Pulau G Pantai Utara Jakarta.

Kajian Lingkungan Hidup Strategis

Raperda Rencana Tata Ruang Kawasan Strategis Pantai Utara Jakarta.
Kementerian Lingkungan Hidup dan Kehutanan. (2017). Reklamasi Pantai Utara Jakarta. Jakarta: Kementerian Lingkungan Hidup dan Kehutanan.

Rencana Pembangunan Jangka Menengah Daerah Provinsi DKI Jakarta Tahun 2013-2017

Sudijanto, Ari. (2017). Arahan Perbaikan Dokumen Lingkungan Reklamasi Pulau C, D E dan Pulau G. Jakarta: Kementerian Lingkungan Hidup dan Kehutanan.

\section{Sumber Internet:}

Badan Pusat Statistik. 2012. Population Of Indonesia by Province 1971, 1980, 1990,1995, 2000, 2010. Tersedia di https://www.bps.go.id/linkTabelSt atis/view/id/1267 (diakses 25 Februari 2017)

Berita SatuTV. 2016. Proyek Reklamasi Teluk Jakarta. Tersedia di https://www.youtube.com/watch? $\mathrm{v}=\mathrm{XZFjmmEH028}$ (diakses 13 Juni 2017)

Biro Informasi dan Hukum Kementerian Koordinator Bidang Kemaritiman RI. 2016. Komite Bersama Reklamasi Pantai Utara Jakarta Segera Tetapkan Rekomendasi 13 Pulau Lain. Tersedia di https://maritim.go.id/komitebersama-reklamasi-pantai-utarajakarta-segera-tetapkan- 
rekomendasi-13-pulau-lain/ (diakses 27 April 2017)

Firmanto, Danang. 2016. Nelayan Menang Pencabutan Izin Reklamasi Pulau G. Tersedia di https://m.tempo.co/read/news/201 6/05/31/083775540/nelayanmenang-gugatan-pencabutan-izinreklamasi-pulau-g (diakses 11 April 2017)

Kementerian Dalam Negeri RI. 2016. Daftar Luas Wilayah Provinsi di Indonesia. Tersedia di http://infopersada.com/nasional/pe merintahan-dan-wilayah/2-daftarluas-wilayah-provinsi-diindonesia.html (diakses 25 Februari 2017)

Kementerian Lingkungan Hidup Republik Indonesia. 2004. Sidang Pertama Gugatan 6 Perusahaan Kontraktor BP Pantura digelar. Tersedia http://www.menlh.go.id/sidangpertama-gugatan-6-perusahaankontraktor-bp-pantura-digelar/ (diakses 11 Juni 2017)

Koalisi Selamatkan Teluk Jakarta. 2016. Somasi Terbuka Menolak Dilanjutkannya Reklamasi Teluk Jakarta. Tersedia di http://www.bantuanhukum.or.id/w eb/somasi-terbuka-menolakdilanjutkannya-reklamasi-telukjakarta/ (diakses 29 September 2016)

Margianto, Heri. 2016. Jalan Panjang Reklamasi di Teluk Jakarta, dari Era Soeharto sampai Ahok. Tersedia di http://megapolitan.kompas.com/re ad/2016/04/04/10050401/Jalan.Pa njang.Reklamasi.di.Teluk.Jakarta. dari.era.Soeharto.sampai.Ahok (diakses 26 April 2017)

Panjaitan, Luhut Binsar. 2016. Reklamasi Jakarta Dilanjutkan, Menko Maritim Jamin Kesejahteraan Nelayan. Tersedia di

https://www.youtube.com/watch? $\mathrm{v}=\mathrm{rKLxPWKdnD0} \quad$ (diakses 21 April 2017)

Republika[dot]co[dot]id. 2016. PTUN Didesak Batalkan Izin Reklamasi Pulau G. Tersedia di http://v2.bkprn.org/?p=2271 (diakses 26 April 2017)

Rochmi, Muhammad Nure. 2016. Memahami Reklamasi Pantai Utara Jakarta. Tersedia di https://beritagar.id/artikel/berita/m emahami-reklamasi-pantai-utarajakarta (diakses 20 September 2016)

Rocky Gunung Hasudungan, dkk. 2014. Statistik Daerah Provinsi DKI Jakarta 2014. Tersedia di http://jakarta.bps.go.id/backend/p df_publikasi/Statistik-Daerah-Provinsi-DKI-Jakarta-2014.pdf (diakses 25 Februari 2017)

Satria, Lintar dan Bayu Hermawan. 2017. Koalisi Selamatkan Teluk Jakarta Tolak Sosialisasi AMDAL Reklamasi. Tersedia di http://nasional.republika.co.id/beri ta/nasional/jabodetabeknasional/17/01/30/okkfgk354koalisi-selamatkan-teluk-jakarta- 
tolak-sosialiasi-amdal-reklamasi (diakses 9 Juni 2017)

Suara Jakarta. 2015. Reklamasi

Pantai Jakarta: Pengembang, Gubernur, atau Penjahat Lingkungan. Tersedia di http://suarajakarta.co/news/politik /reklamasi-pantai-jakartapengembang-gubernur-ataupenjahat-lingkungan/ (diakses 29 September 2016) 